Bangladesh J. Sci. Res. 27(1): 99-108, 2014 (June)

\title{
SHORELINE CHANGES ALONG THE KUTUBDIA ISLAND, SOUTH EAST BANGLADESH USING DIGITAL SHORELINE ANALYSIS SYSTEM
}

\author{
Md. Ashraful Islam*, Md. Shakhawat Hossain ${ }^{1}$, Tanzeer Hasan and Sanzida Murshed \\ Department of Geology, University of Dhaka, Dhaka-1000, Bangladesh
}

\begin{abstract}
A $\sim 65 \mathrm{~km}$ coastal stretch has been analyzed to estimate the change dynamics of Kutubdia Island with the help of digital shoreline analysis system (DSAS). This study investigated the reliability of medium resolution satellite imagery for mapping shoreline positions and for estimating historic rates of changes. Nine shoreline positions were extracted on 1972, 1976, 1980, 1989, 1999, 2004, 2009, 2011 and 2014 covering a long term of 42 years period. Rates of shoreline changes were estimated by four statistical methods namely, end point rate (EPR), linear regression rate (LRR), weighted linear regression (WLR) and least median of squares (LMS) by using DSAS and subsequently all the methods were verified with the correlation coefficient (R).The scrutiny of shoreline changes shows that the erosion during the last 42 years has affected the island, with some exception, at the north and west segment where minor accretion has been documented. The average rates of changes estimated for north, south, east and west segment using WLR, LMS, EPR and LRR are Ñ4.0 $\mathrm{m} / \mathrm{yr}, \tilde{N} 33.7 \mathrm{~m} / \mathrm{yr} \tilde{N} 2.6 \mathrm{~m} / \mathrm{yr}$ and $\tilde{N} 5.6 \mathrm{~m} / \mathrm{yr}$, respectively. The outcome of this particular analysis might be useful for proper planning and management of Kutubida Island. However, this may also be used in statistical modeling for forecasting the future shoreline position.
\end{abstract}

Key words: Digital shoreline analysis system, end point rate, linear regression rate, weighted linear regression, least median of squares

\section{Introduction}

Shoreline could be defined as the physical interface of land and water (Dolan et al. 1980) aid in providing valuable information about the coastal process as well as the shoreline dynamics. Monitoring coastal shorelines for environmental protection is an important task (Rasuly et al. 2010). According to the Intergovernmental Panel on Climate Changes (IPCC) Fourth Assessment Report (AR4), the coastal vulnerability assessments still focus mainly on sea level rise where monitoring of the historical shoreline can prove to be an important criterion for the assessment (IPCC 2007). A series of dynamic natural processes including coastal erosion, sediment transport, tide, sea level rise and coastal

*Corresponding author: <ashrafhimel@du.ac.bd >. ${ }^{1}$ Department of Disaster Science and Management, University of Dhaka, Dhaka-1000, Bangladesh. 
geomorphology, account for changes in the shoreline. Bangladesh is considered as one of the most vulnerable countries in the World to the impacts of climate change, particularly sea-level rise (Warrick and Ahmad 1996, Cruz et al. 2007, Nicholls et al. 2007, Karim and Mimura 2008) and threaten by coastal erosion. Historic maps, aerial photographs, beach profiles, topographic and bathymetric surveys etc. can be used to qualitatively and quantitatively evaluate the spatial and temporal changes in coastal areas. These dataset might provide a variety of means to analyze the rates of changes of shoreline position. It is well documented that Remote Sensing together with Geographic Information System (GIS) can quantify the coastal processes, erosion and accretion especially in the last decades ( Durduran 2010, Sener et al. 2010) and being used as a robust combined tool for the coastal vulnerability assessment as well. Various methods for coastline extraction from optical imagery have been developed (Bosworth et al. 2003, Di et al. 2003, Foody et al. 2005, Dewidar and Frihy 2008). Assessing the amount of erosion and accretion has become critical for the management of coastal zone and socio-economic developments. Shoreline variability and trend analysis largely depends on exact shoreline delineation and is a complex and time-consuming task. However, temporal and spatial dimensionality must be taken care for shoreline demarcation during investigation.

The Kutubdia, one of the major off-shore island, lying on the south-eastern part of Bangladesh coast has got much attention due to its rapid loss of land to sea which has turned out to be a recurrent phenomenon in recent time due to sea level rise. The present analysis attempts to estimate the rate of changes pertaining to Kutubdia coastline with the help of geospatial techniques using nine multi-temporal satellite imagery.

The study area: Kutubdia Island lies between latitude $21^{\circ} 44^{\prime} 23^{\prime \prime}$ to $21^{\circ} 55^{\prime} 24^{\prime \prime} \mathrm{N}$ and longitude $91^{\circ} 50^{\prime} 40^{\prime \prime}$ to $91^{\circ} 54^{\prime} 04^{\prime \prime} \mathrm{E}$, situated in the south-eastern part of Bangladesh having an area of $215.8 \mathrm{~km}^{2}$ and separated from the main land by Kutubdia channel. The island is north-south elongated, approximately $20 \mathrm{~km}$ long and $5.5 \mathrm{~km}$ wide (Fig. 1). The present study area consists of six unions which are Ali Akbar Deil, Baraghop, Dakshin Dhurung, Kaiyarbil, Lemsikhali and Uttar Dhurung. Population of Kutubdia is 1,25,279 according to census 2011(BBS 2011). Geologically this island is young and getting its present shape in the Holocene time dominantly consists of unconsolidated sediments. Major physiographic unit of Kutubdia Island is young coastal plain having average elevation of $\sim 6$ meters surrounded by active coastal plain. According to Majlis et al. 2013 , major portion of the study area dominantly consists of tidal deposits, i,e intertidal and supratidal deposits composed of sitly clay with organic clay mix and little sand whereas beaches and dunes are composed of loose fine to medium sand with considerable amount of heavy minerals. The study area facing strong long shore currents in the rainy season which eventually cause rapid erosion in the southern and western shorelines. This area is characterized by tropical and subtropical climate. Monsoon period 
is the chief source of rainfall. About $90 \%$ of the annual rainfall occurs during this time period, beginning in May and continuing up to September which is more than $380 \mathrm{~mm}$. The study area is particularly susceptible to cyclone and tidal surges.

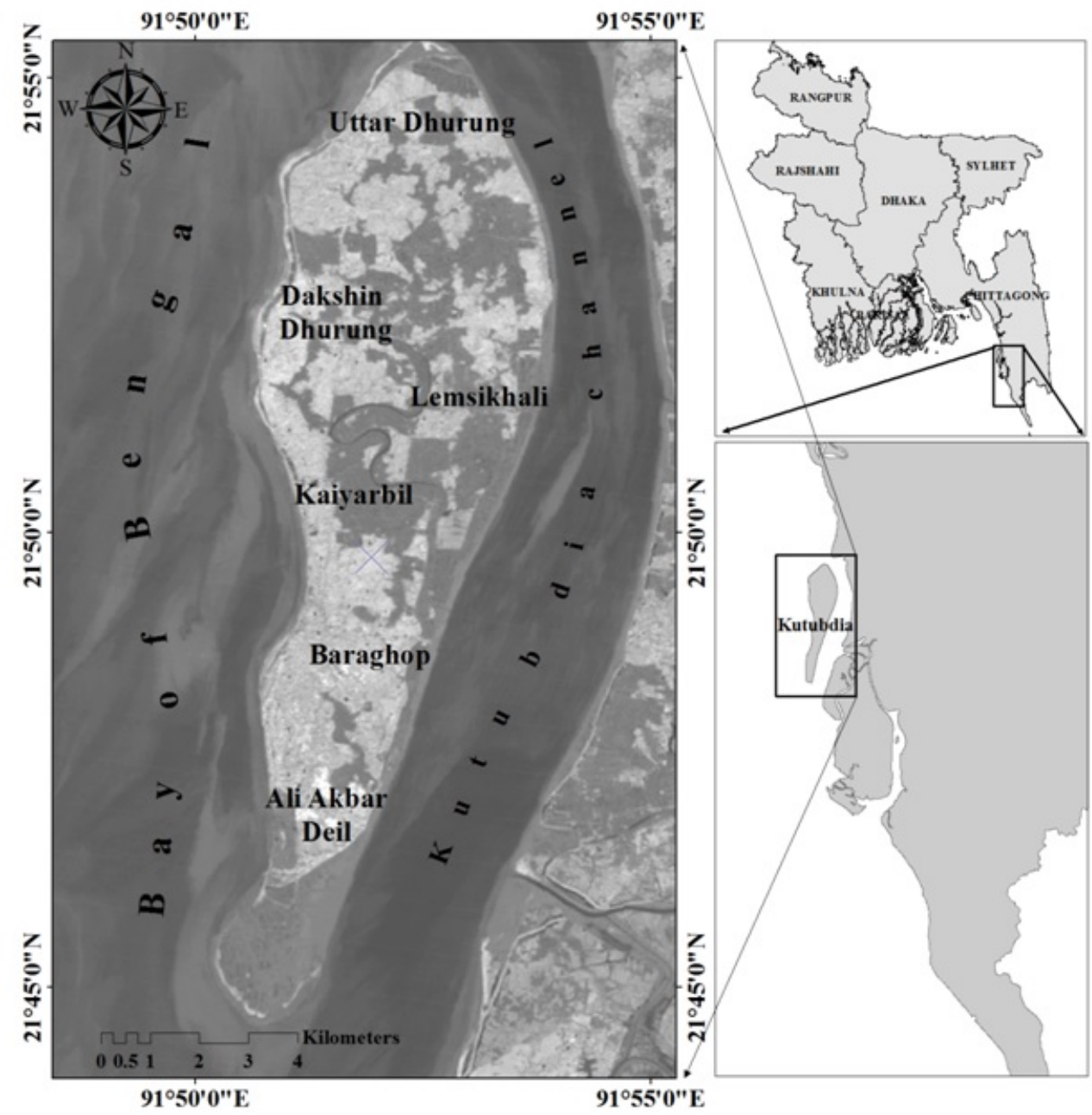

Fig. 1. Location map of the study area

\section{Materials and Methods}

Data used: The present study was carried out with multi-temporal imagery of Landsat MSS (Multispectral Scanner), TM (Thematic Mapper) and ETM+ (Enhanced Thematic Mapper) and OLI (Operational Land Imager) which were chosen as cloud free and high tide synchronous (Table 1) covering 42 years time frame for monitoring shoreline 
changes along the Kutubdia Island. All these imagery were down loaded from USGS global visualization viewer (Glovis 2014) and subset according to the area of interest.

All the imagery was projected in UTM projection with zone no. 46 and WGS 84 datum. After layer stacking and subset, few spatial enhancement techniques were adopted to have a better visualization for shoreline demarcation. Processing was done using Erdas imagine 11, digitization and final statistical analysis were done by ArcGIS 10 and DSAS 4.2 (an extension of ArcGIS 10), respectively.

Table 1. List of satellite imagery.

\begin{tabular}{cccccc}
\hline Serial no. & Satellite and sensor & Date & Path & Row & Spatial resolution $(\mathrm{m})$ \\
\hline 1 & LANDSAT MSS & $1972-12-27$ & 146 & 045 & 60 \\
2 & LANDSAT MSS & $1976-01-26$ & 146 & 045 & 60 \\
3 & LANDSAT MSS & $1980-01-14$ & 146 & 045 & 60 \\
4 & LANDSAT TM & $1989-01-05$ & 136 & 045 & 30 \\
5 & LANDSAT ETM & $1999-12-19$ & 136 & 045 & 30 \\
6 & LANDSAT ETM & $2004-01-15$ & 136 & 045 & 30 \\
7 & LANDSAT ETM & $2009-01-12$ & 136 & 045 & 30 \\
8 & LANDSAT ETM & $2011-01-02$ & 136 & 045 & 30 \\
9 & LANDSAT OLI & $2014-02-19$ & 136 & 045 & 30 \\
\hline
\end{tabular}

Source: http://glovis.usgs.gov/

Shoreline delineation: The coast lines are much more dynamic in nature and changing all the time due to its diurnal tidal effect. As a consequence the exact, shoreline demarcation is somewhat difficult. Despite the fact, it would be possible to delineate shorelines both automatically, semi automatically and even manually. For this study, well registered, of better radiometric resolution and cloud free multi-temporal Landsat imagery were used to accomplish the objective. A Band ratio technique has been shown to be an efficient approach to automated shoreline identification (Alesheikh et al. 2007) and after little manual correction may give well defined shoreline with less error in any coastal region. Band indices NDVI (Normalized differentiate vegetation index) has widely been used as distinct separation between the land and water using infrared band and red band.

Statistical analysis: In this study DSAS version 4.2 (Thieler et al. 2009) an extension program of ArcGIS10 software was used to calculate the rate of shoreline changes. To calculate the rate of shoreline change, the years 1972, 1976, 1980, 1989, 1999, 2004, 2009, 2011 and 2014 in the vector format (polyline) were used as the input data to the DSAS. This extension (DSAS) having three main components that defines a baseline, generate orthogonal transects at a user-defined separation along the coast, and calculates rates of change (linear regression, endpoint rate, etc.). Based on this setting, users are 
allowed to generate transects with any interval along shore. In this context, transects were cast at simple right angles from the baseline at $100 \mathrm{~m}$ interval covering the entire shoreline ( $65 \mathrm{kms}$ ) with 420 transects (Fig. 2). Eventually the data measured from each

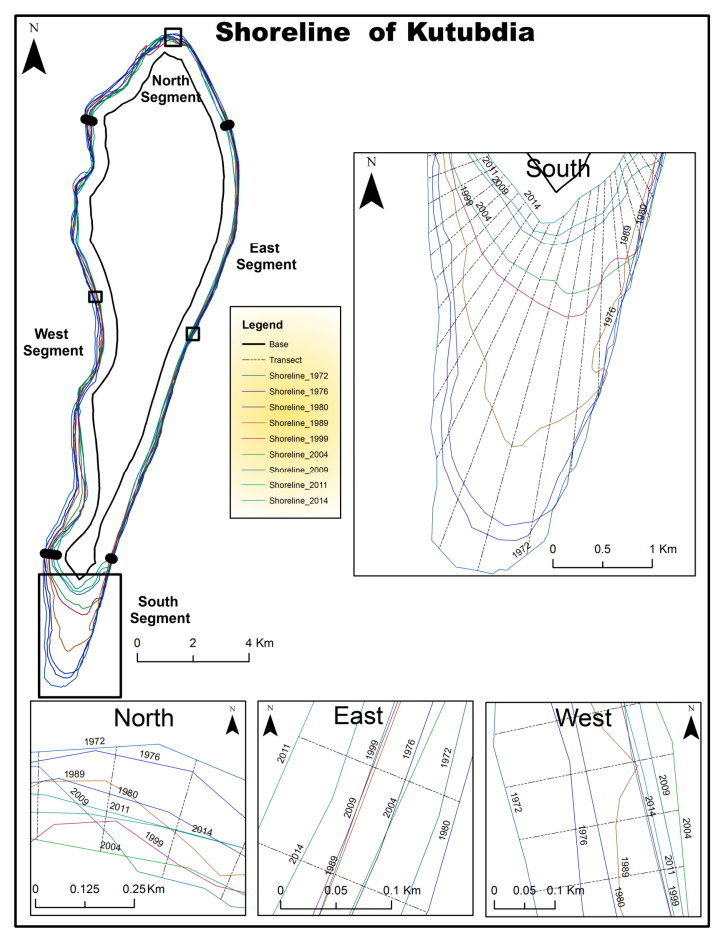

Fig. 2. Positions of shorelines (1972 - 2014) and transect lines (Highlighted rectangular boxes are shown west, east, north and south segments of Kutubdia Island).

transect were used to estimate the shorelines change rates ( $\mathrm{m} / \mathrm{yr})$ applying number of well recognized statistical methods i.e., end point rate (EPR), linear regression rate (LRR), weighted linear regression (WLR) and least median of square (LMS) techniques. Linear regression method has been used since it is universally practiced statistical technique for expressing shoreline movement and estimating rates of change (Crowell et al. 1997). The linear regression method is susceptible to outlier effects and also tends to underestimate the rate of change relative to other statistics, such as EPR (Dolan et al. 1991, Genz et al. 2007). The end point rate (EPR) is calculated by dividing the distance of shoreline movement by the time elapsed between the oldest and the most recent shoreline. In the present analysis, EPR was done over the oldest (1972) and the youngest (2014) shorelines. The major advantages of the EPR are the ease of computation and minimal requirement of only two shoreline dates. However the rest of the shorelines are ignored during because of its computational limitation (Thieler et al. 2009). 


\section{Results and Discussions}

The perpendicular transect location between the measurement baseline and historical shoreline was used to determine the rate of shoreline changes of Kutubdia Island. Table 2 shows the rates of shoreline change calculated by DSAS where the positive value signifies accretion and negative value corresponds to the rate of erosion. The rate of shoreline change is analyzed in four locations of the island: North, south, east and west (Fig. 2). Erosion is dominant in the whole island. The LMS, EPR, LRR and WLR methods exhibit the highest erosion rates around the southern part of the island. North segment having 70 transect locations where only 5 transects are found to report accretion by LMS and WLR and 6 transect by LRR but all other transects documented erosion. The statistical analysis by EPR identifies two locations of accretion by considering the old and recent shoreline. EPR analysis is over generalized in a sense that intermediate shorelines are ignored here. Whereas in the west segment, among 168 transects, 18 are found to report accretion by LMS, WLR and LRR whereas EPR shows 9 transects as erosion. In the south and east segment erosion is dominant. All the transect locations are showing erosion by EPR, LRR and WLR with exception where LMS reveals only one transect location as accretion in the south segment and three transects in the east.

Table 2. Statistics of Kutubdia shoreline in different segments from 1972 to $2014(\mathrm{~m} / \mathrm{yr})$

\begin{tabular}{cccccc}
\hline Segments & Statistical characters & LMS & EPR & LRR & WLR \\
\hline \multirow{4}{*}{ North } & Max. & 1.87 & 0.29 & 2.91 & 3.53 \\
& Min. & $\tilde{N} 11.19$ & $\tilde{N} 8.56$ & $\tilde{N} 7.39$ & $\tilde{N} 7.84$ \\
& Mean & $\tilde{N} 4.05$ & $\tilde{N} 4.03$ & $\tilde{N} 3.84$ & $\tilde{N} 4.09$ \\
& SD & 2.95 & 2.05 & 2.39 & 2.53 \\
\multirow{5}{*}{ South } & Max. & 0.35 & $\tilde{N} 10.58$ & $\tilde{N} 7.34$ & $\tilde{N} 9.61$ \\
& Min. & $\tilde{N} 64.45$ & $\tilde{N} 94.67$ & $\tilde{N} 96.04$ & $\tilde{N} 95.84$ \\
& Mean & $\tilde{N} 28.33$ & $\tilde{N} 35.94$ & $\tilde{N} 34.42$ & $\tilde{N} 36.16$ \\
& SD & 23.46 & 27.13 & 28.62 & 27.87 \\
\multirow{5}{*}{ East } & Max. & 4.34 & $\tilde{N} 0.44$ & $\tilde{N} 0.49$ & $\tilde{N} 0.3$ \\
& Min. & $\tilde{N} 6.39$ & $\tilde{N} 8.74$ & $\tilde{N} 4.82$ & $\tilde{N} 6.57$ \\
& Mean & $\tilde{N} 2.42$ & $\tilde{N} 3.04$ & $\tilde{N} 2.38$ & $\tilde{N} 2.76$ \\
& SD & 1.21 & 1.19 & 0.79 & 1.01 \\
\multirow{2}{*}{ West } & Max. & 4.75 & 2.7 & 4.97 & 5.08 \\
& Min. & $\tilde{N} 14.71$ & $\tilde{N} 15.77$ & $\tilde{N} 15.3$ & $\tilde{N} 14.7$ \\
& Mean & $\tilde{N} 4.96$ & $\tilde{N} 6.50$ & $\tilde{N} 5.52$ & $\tilde{N} 5.47$ \\
& SD & 4.38 & 4.28 & 4.49 & 4.44 \\
\hline
\end{tabular}


A correlation study was conducted between different statistical analyses (Fig. 3). A very satisfactory agreement is found among all statistical processes. In the west segment of Kutubdia Island, the statistical analysis shows that the correlation of determination between rates estimated using WLR, LMS, EPR and LRR are $93 \%$ indicating that the general trends of changes are similar. The maximum correlation of determination is estimated using WLR and LRR and the minimum is found between EPR and LMS (Fig. $3)$. The average rates of changes estimated for west segment using WLR, LMS, EPR and LRR is more than N $5 \mathrm{~m} / \mathrm{yr}$ that is estimated between transect ID 241 to transects ID 404. The accretion zone was identified between transect ID 338 to transect ID 345. In the East segment of Kutubdia Island, the correlation of determination between rates estimated
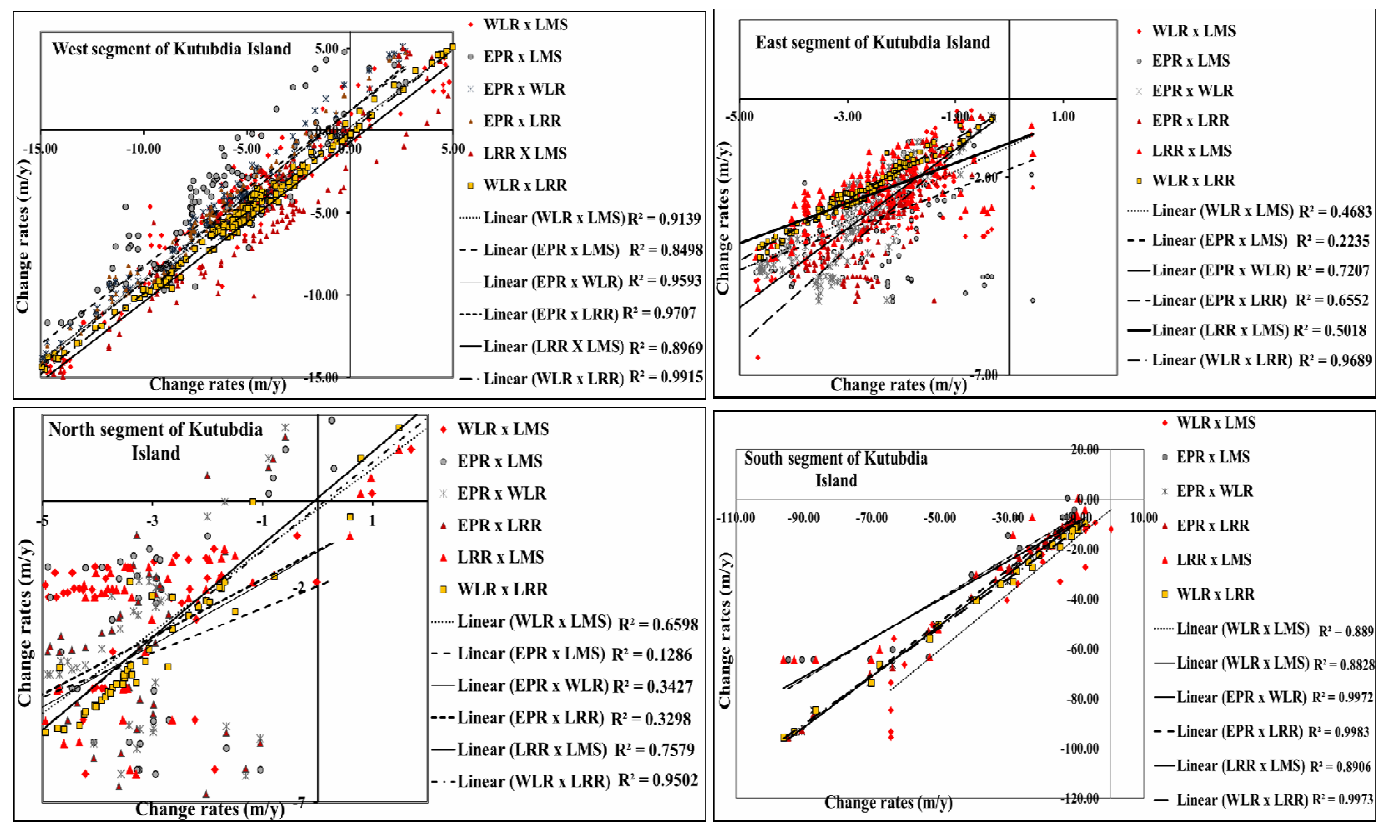

Fig. 3. Correlation between various statistical measurements pertain to rate of change estimated for four different segments of the study area.

using WLR, LMS, EPR and LRR is 59\%. The maximum correlation of determination is estimated 0.96 using WLR and LRR whereas a poor correlation coefficient is found between rates estimated by EPR and LMS. The average rate of changes estimated for east segment using all methods is more than $\tilde{N} 2.5 \mathrm{~m} / \mathrm{yr}$ that is estimated between transect ID 9 to transect ID 170. The whole segment is under erosional stage. Whereas, the correlation of determination between rates estimated using all methods in the north and south segment are $53 \%$ and $94 \%$, respectively. 
The maximum correlation of determination is estimated 0.95 using WLR and LRR for north segment whereas in the south segment this correlation of determination is estimated 0.99 using EPR and LRR. In both segments, the minimum correlation of determination is estimated by EPR and LMS but very poor correlation is found when using north segment. In the south segment, more than 0.99 correlations are found between rates estimated by EPR, WLR and LRR. Good agreement between individual correlation coefficient infers that the rate estimation using various statistical parameters are consistent and signifies authentic results pertaining to coastal land change in Kutubdia island.

\section{Conclusion}

Appraisal of the spatial dynamics of the coastal system essentially requires the reviewing of historical evolution and temporal morpho-dynamics of shoreline position and geometry. The objective of the present study was to evaluate the application of multi temporal satellite data along with statistical techniques in the prediction of shoreline changes and its dynamic nature. In this context, geospatial techniques i.e., the remote sensing and Geographic Information System (GIS) were used combined with the statistics for the coastal erosion vulnerability assessment. The coast of Kutubdia is exceptionally dynamic. Time series analysis of Landsat imagery from 1972 to 2014 have revealed that more than 400 transect appeared to have experienced a change mostly in erosional phase. Segments based analysis of shoreline changes using DSAS reveals that southern part of the shoreline is suffering from severe erosion, whereas eastern, western and northern segments having relatively less erosion during last 42 years. Correlation coefficients of the measured statistical parameters WLR, LMS, EPR and LRR indicate that the general trends of changes are similar. The maximum correlation of determination is estimated more than 93\% using WLR and LRR for all statistical methods and the minimum is found between EPR and LMS. The average rates of changes estimated for north, south, east and west segment using WLR, LMS, EPR and LRR are Ñ4.0 m/yr, $\tilde{N} 33.7 \mathrm{~m} / \mathrm{yr} \tilde{N} 2.6 \mathrm{~m} / \mathrm{yr}$ and Ñ $5.6 \mathrm{~m} / \mathrm{yr}$, respectively. Major portion of the Kutubdia Island (South and west segment) is exposed to open sea and is influenced by the strong wave actions as well as seasonal cyclones, sea level rise and de-sedimentation eventually accelerated erosion, however the effect of long shore currents cannot be overlooked. On the other hand the north and east segments experience relatively less erosion. From this particular study it is insisted to take special care for the future planning and management of Kutubdia Island for further erosion. However, care has to be taken during accomplishing the mitigation measurements so that the natural processes are not obliterated. 


\section{References}

Alesheikh A. A., A. Ghorbanali and N. Nouri. 2007. Coastline change detection using remote sensing. Int. J. Environ. Sci. Technol. 4:61-66.

BBS. 2011. Bangladesh Bureau of statistics. Population Census 2011.

Bosworth, J., T. Koshimizu. and S.T. Acton. 2003. Multi-resolution segmentation of soil moisture imagery by watershed pyramids with region growing merging. Internat. J. Remote Sensing 24(4): 741-760.

Crowell, M., B.C. Douglas. and S.P. Leatherman.1997. On forecasting future US shoreline positions: a test of algorithms. J Coast Res. 13(4): 1245-1255.

Cruz, R.V., H. Harasawa., M. Lal., S.Wu., Y. Anokhin., B. Punsalmaa., Y. Honda., M. Jafari., C.Li. and N.H. Ninh. 2007. Asia. In: Parry, M.L., O.F. Canziani., J.P. Palutikof., P.J.Linden.and C.E. Hanson. (eds) Climate change 2007: Impacts, adaptation andvulnerability. Contribution of working group II to the fourth assessment report of the intergovernmental panel on climate change. Cambridge University Press, Cambridge. 469506.

Dewidar, Kh. and O. E. Frihy. 2008. Pre and post-beach response to engineering hard Structures using landsat time-series at the northwestern part of the nile delta, Egypt. J. Coastal Conservation 11(2):133-142.

Di, K., J. Wang., R. Ma. and R. Li. 2003. Automated shoreline extraction from high resolution IKONOS Satellite Imagery. Proceedings of the ASPRS 2003 Annual Conference, Anchorage, May 2003.

Dolan, R., B.P. Hayden., P. May and S.K. May. 1980. The reliability of shoreline change measurements from aerial photographs. Shore and Beach 48(4): 22-29.

Dolan, R., M.S. Fenster. and S.J. Holme. 1991. Temporal analysis of shoreline recession and accretion. J. Coastal Research 7:723-744.

Durduran, S. S. 2010. Coastline change assessment on water reservoirs located in the konya basin area, Turky, using multitemporal Landsat imagery. Environ. Monitoring Assessment 164: 453461.

Foody, G. M., A. M. Muslim. and P. M. Atkinson. 2005. Super-resolution mapping of the Waterline from remotely sensed data. Internat. J. Remote Sensing 26(24): 5381-5392.

Genz, A.S., C.H. Fletcher., R.A. Dunn., L.N. Frazer. and J.J. Rooney. 2007. The predictive accuracy of shoreline change rate methods and alongshore beach variation on Maui, Hawaii. J. Coastal Research 23(1): 87-105.

GLOVIS (USGS Global Visualization Viewer). 2014. USGS science for a changing world.http://glovis.usgs.gov/. Accessed 12 February, 2014.

IPCC, 2007. Summary for Policy makers. In: Soloman, S.D., Q.M. Manning., Z. Chen. and H.L. Miller (ed) Climate Change 2007. The physical science basis. contribution of working group I to the Fourth Assessment Report of the Intergovernmental Panel on climate change. Cambridge University Press, Cambridge. 1-18. 
Karim, M.F. and N. Mimura. 2008. Impacts of climate change and sea-level rise on cyclonic storm surge floods in Bangladesh. Glob. Environ. Chang. 18: 490-500.

Majlis, A.B.K., M.A. Islam., M.H. Khasru. and M.K. Ahsan. 2013. Protected to Open basin depositional system: an appraisal for the late quaternary evolution of the Moheshkhali Kutubdia coastal plain, Bangladesh. Bangladesh J. Geology 31-32: 16- 28.

Nicholls, R.J., P.P. Wong., V.R. Burkett., J.O. Codignotto., J.E. Hay., R.F. McLean., S. Ragoonaden and C.D. Woodroffe. 2007. Coastal systems and low-lying areas. In: Parry, M.L., O.F. Canziani, J.P. Palutikof, P.J. Linden and C.E. Hanson (eds) Climate change 2007: Impacts, adaptation and vulnerability, contribution of working group II to the fourth assessment report of the inter governmental panel on climate change. Cambridge University Press, Cambridge. 315-356.

Rasuly, A., R. Naghdifar and M. Rasoli. 2010. Monitoring of caspian sea coastline changes using object-oriented techniques. Proc. Environ.l Sci. 2: 416-426.

Sener, E., A. Davraz. and S. Sener. 2010. Investigation of Ak- sehir and Eber Lakes (SW Turky) coastline change with multi temporal Satellite Images. Water Resources Management 24(4): 727-745.

Thieler, E.R., E.A. Himmelstoss, J.L. Zichichi., Ergul and Ayhan. 2009. Digital shoreline analysis system (DSAS) version 4.0 - An ArcGIS extension for calculating shoreline change: U.S. Geological Survey Open-File Report 2008-1278. *current version 4.2.

WARPO. 2006. Coastal development strategy. Water resources planning organization (WARPO), Ministry of Water Resources, Government of the People`s Republic of Bangladesh, Dhaka.

Warrick, R.A. and Q.K. Ahmad. 1996. The implications of climate and sea level change for Bangladesh. Kluwer Academic Publishers, Dordrecht.

(Manuscript received on 26 May, 2014; revised on 07 June, 2014) 